\title{
V. Tăpkova-Zaimova, A. Miltenova, Historical and Apocalyptic Literature in Byzantium and Medieval Bulgaria, East-West Publishers, Sofia 2011, pp. 605.
}

About fifteen years ago, we expected with enthusiasm the publication of the first edition of V. Tăpkova-Zaimova and A. Miltenova’s book on the historical and apocalyptic literature in Byzantium and Medieval Bulgaria. We had already waited for more than five years and our expectation was becoming somehow hopeless. When finally the book appeared, we were happy but also sad: happy because of the quality of the text, sad because of the book's poor printing quality. This was the way in which Sofia University Publishing House worked at that time. I do not wish to occupy the attention of the reader with these old problems, but to emphasize the qualities of the new edition, and to congratulate the authors, the publisher, and all the people who contributed to it realisation.

It is to note that this is not only a better reprint or a simple English translation of the former edition. The book is completely revised in terms of research and commentary, and several new texts are added to the list of the original historical and apocalyptic works. Having in mind its importance for all the specialists in mediaeval studies (historians, philologists, philosophers, theologians and so forth), I believe that it is worthy to announce the appearance of the revised edition and to highlight that it came to us at the right moment: the year of the International Congress of Byzantine Studies in Sofia (August, 2011).

The new edition retains the general structure of the first but with some new and essential changes. It could be divided in two parts: a study (or studies) on the apocalyptic tradition in Byzantium and in the satellite countries, followed by an edition of the original sources. The remarkable introductory research of V. TăpkovaZaimova is kept and developed by the author. It covers the Introduction and three studies united under the title Mythology and Real History. The
Introduction deals with the origins, development and periodisation of the apocalyptic literature in the Eastern Roman Empire, its appearance in Jewish milieu, and its reception by the Christian New Rome. It also provides a survey of the translations of the literary works belonging to the apocalyptic literature in the countries of the 'Byzantine World', and their manuscript tradition as it arrived to our times.

The above-mentioned three studies focus on three main problems of the historical-apocalyptic literature: The Succession of the Earthly Kingdoms and the Holy Cities, The Figure of the Ideal King-Saviour and the Real Historical Characters and Nations: Historical Reality and Myth. Sure, this is an essential contribution in the domain of the history of ideas in the Byzantino-Slavic tradition. Having undertaken this type of research, I should confess that my approach and methods are not completely the same as those we find in the three studies. I am not convinced that we should always seek a historical archetype for every apocalyptic figure or to read the text from a somewhat "national" or ethnically determined point of view. The historical-apocalyptic literature is obviously linked to the Hebrew heritage and the biblical archetypes - to the "great code" of the Christian art and literature - which dominated (and still continue in) the European culture since two millennia ago. It is to state that in this respect the research as presented in the book is quite balanced and very well carried out.

Here I shall not deal in detail with the original texts, which are published in the revised book. Most of them are known from the first edition. I shall say only that the studies of the manuscript copies and of the whole manuscript tradition, as well as the commentaries are much larger and enhanced with the new research on the topic. The texts are subdivided into three cycles: 1 . The cycle of the late $11^{\text {th }}$ century (Vision 
and Interpretation of Daniel, Narration of Isaiah, Revelation of Methodius Patarensis, Commentary of Hippolytus of Rome and of Hypatius of Ephesus, so called Bulgarian Apocryphal Chronicle); 2. The cycle of $13^{\text {th }}-14^{\text {th }}$ centuries (The Visions of Prophet Daniel, Vision of the Prophet Isaiah of the Last Times, Pandeh's Prophetic Story, Apocalypsis of St. Andrew the Fool-in-Christ's-Sake, The Legend of the Antichrist, Tale of the Twelve Dreams of King Shahinshahi, Oracles of Leo, Story of Sybil, Razumnik-Ukaz); 3. The last two texts (Sermon on the Ishmaelites of the Last Times, Legend of the Turkish Invasion) are dated in the Early Ottoman époque in the Balkans. These last two texts and the four literary works linked to St. Andrew the Foolin-Christ's-Sake, Antichrist, Shahinshahi and Emperor Leo are new and were not published in the first edition of the book. It is to note that the above-mentioned subdivision of the book in three parts is not based on a reinterpretation of the genesis of the original texts (Greek or Near Eastern), but on their arrival and adoption in the Bulgarian mediaeval literature.

I would like to present as well the structure of every section containing an original text. In many respects they repeat the structure inherited from the first edition: we find a study on the text (its manuscript tradition, its historical and ideological meaning, historiography, former publications, and so forth), followed by an edition of the original text, its Bulgarian and English translations, the latter with notes of commentary. The book is in English but I think that it is admirable that the authors kept the Bulgarian translations as well. Obviously, the Bulgarian readers are among the main addressees of the book. Being very favourable to the book structure, I cannot avoid mentioning that unfortunately in some cases this is abandoned: there are no translations of the Sermon of the Antichrist, nor of the Oracles of Leo. The section with the texts of the Ottoman period is completely confused and does not correspond to the abovementioned general structure. I do not believe that the book became better by these deviations.

With these minor critical remarks, I do not wish at all to put any doubt on the high qualities of the book. The second edition, like the first one, is an important event in both Byzantine and Bulgarian mediaeval studies. All of us who work in these fields have read with great interest the authors' research, which broadens our understanding of essential ideological concepts in the Byzantine World. Furthermore, the book of V. Tăpkova-Zaimova and A. Miltenova makes an important contribution to our knowledge of the influence exercised by the Holy Scripture and the related deuterocanonical literature not only upon the mediaeval culture, but also upon the succeeding époques. We have therefore to be grateful to the authors and to all the colleagues who contributed to this edition, and to expect them to continue on this path.

Ivan Biliarsky (Sofia)

Священное Писание как фактор языкового и литературного развития. Материаль Международной конференции „Священное Писание как бактор языкового и литературного развития (в ареале авраамических религий)", Санкт-Петербург, 30 июня 2009 г., еd. Е.Н. МЕщЕРСКАя, Издательство «Дмитрий Буланин», Санкт-Петербург 2011, pp. 336.

This publication is a collection of studies dedicated to the head of the Department of Biblical Studies at the State University of St. Petersburg, a prominent specialist on the history of Old Russian literature and Russian language,
Professor Anatoliy A. Alekseev, on the occasion of his $70^{\text {th }}$ birthday. The articles, comprising the analyzed volume, are characterized by considerable uniform theme. Most of them were in fact presented at the International Conference 